Near-East Problems in the Second Pre-Christian Millenium

Author(s): A. T. Olmstead

Source: The Journal of Egyptian Archaeology, Vol. 8, No. 3/4 (Oct., 1922), pp. 223-232

Published by: Egypt Exploration Society

Stable URL: http://www.jstor.org/stable/3853704

Accessed: 12-05-2016 17:25 UTC

Your use of the JSTOR archive indicates your acceptance of the Terms \& Conditions of Use, available at

http://about.jstor.org/terms

JSTOR is a not-for-profit service that helps scholars, researchers, and students discover, use, and build upon a wide range of content in a trusted

digital archive. We use information technology and tools to increase productivity and facilitate new forms of scholarship. For more information about JSTOR, please contact support@jstor.org.

Egypt Exploration Society is collaborating with JSTOR to digitize, preserve and extend access to The Journal of Egyptian Archaeology 


\title{
NEAR-EAST PROBLEMS IN THE SECOND PRE-CHRISTIAN MILLENIUM
}

\author{
By Professor A. T. OLmSTEAd
}

The discovery of the Hittite archives ${ }^{1}$ has forced us to reconsider the history of the middle of the second pre-Christian millenium, when for the first time in ancient history there developed a condition not far from the balance of power of modern Europe. The investigation of the new documents has already gone far, and particular attention has been directed to the relations with Egypt ${ }^{2}$. No student has directed especial attention to the Assyrian relations, though the new discoveries at Ashur have made possible important additions to our knowledge ${ }^{3}$. The present paper is a supplement to one giving what was then known of early Assyrian history ${ }^{4}$, and repeats what was there said only in so far as is necessary for the general picture of the Near East in the period and for showing the new light in which these events can be studied.

The early part of the second millenium is a period of growing darkness and of disintegration for the two great countries, Egypt and Babylon, which have hitherto given us virtually all our information as to the history of the Near East. In Babylonia, the empire built up by Hammurapi rapidly went to pieces in the incapable hands of his descendants ${ }^{5}$. Under the reign of his son Samsu-iluna, south Babylonia was already lost to the so-called second Babylonian dynasty (2053), and in 1926 the first dynasty glimmered out. Henceforth, weak as it was, the second dynasty was accepted as the chief power of the alluvium, though only south Babylonia was in its control, and here such states as Uruk under Sin-gashid defied its kings.

Later scribes declared that the Hittites were responsible for its downfall ${ }^{6}$. A Hittite inscription found in Babylon has been cited in proof, but the writing is the late cursive and the character of the art points to somewhere about the tenth, not the twentieth

1 Keilschrifttexte aus Boghazköi, I, ff.; native documents of historical nature, Hroznxं, Hethitische Keilschriftexte aus Boghazköi; those in Babylonian translated, Luckenbill, AJSL. XXXVII, $161 \mathrm{ff.}$

2 Meissner, ZDMG. LXXII, $32 \mathrm{ff.;} S B$. Berl. 1917, $282 \mathrm{ff}$; Langdon-Gardiner, Journal VI, $179 \mathrm{ff}$. The Egyptian material is collected in PAton, Egyptian Records of travel; cf. BREASTED, Records of Ancient Egypt; History of Egypt. The Amarna letters are cited by the numbers of Knudtzon, Die el-Amarna-Tafeln; a new edition of the Berlin letters, Schroeder, Die Tontafeln von el-Amarna.

3 WuIDNer, MDOG. LVIII, 1 ff.; MVAG. 1915, 4; 1921, 2.

4 Olmstead, AJSL. XXXVI, $120 \mathrm{ff}$; cf. AJSL. XXXVIHI, $225 \mathrm{ff}$. for corrections in detail made necessary by the new data presented by WeIDNer.

5 Detailed study, Olmstead, A.JSL. XXXV, $87 \mathrm{ff} . \quad{ }^{6} \mathrm{King}$, Chromicles IT, 10. 
century ${ }^{1}$. A Hittite ruler of the early thirteenth century, on the contrary, emphatically asserts to a Babylonian monarch that the sons of Hatti never subjugated the sons of Kar-Duniash ${ }^{2}$. On the other hand, a ruler of the third Babylonian dynasty, who ruled somewhere about the end of the seventeenth century, brought back the statue of Marduk, the god-ruler of Babylon from Hana, whither he had been carried off ${ }^{3}$. This must refer to the end of the first Babylonian dynasty. Now Hana or Hanat is perfectly well known, and is referred to numerous times in the earlier literature. It is the modern 'Ana, the most beautiful island in the middle Euphrates ${ }^{4}$. If Marduk was carried off to the capital of the kingdom which destroyed the first dynasty of Bábylon, that capital was on the middle Euphrates.

Now the fall of Babylon took place, in 1926; this date is exact, as it is based on astronomical calculations which are generally, though not universally, accepted. Not far from this time we find a very powerful ruler in this region, Shamshi-Adad I. The date assigned by WEIDNER is 1892-1860, but this is secured by dead reckoning only, and at a distance from the base to permit a considerable error. It may therefore well be that he can be pushed back to 1926 .

We have hitherto called him an Assyrian ruler, but although in his Ashur inscriptions he attributes the initiation of his activities to Ashur who loves him, there is no indication of a city state of Ashur. Although the first ruler whose name appears at Ashur to take the title of king, he does not receive it from Ashur and his father Igurkapkapu is not counted in the Assyrian lists. His own title is that of "King of the Universe," an old title formerly connected with the extreme north of Babylonia. He "devotes his energies to the land between the Tigris and Euphrates rivers," and he set up an inscription in Tirqa on the Euphrates where he built a temple to the west Semitic god Dagan. He could very well be the king who carried off the cult statues to Hana, which was located in the center of his own country.

He also set up a memorial tablet in the city of Laban, by the shore of the great sea. This is a definite claim to ownership of Lebanon and North Syria ${ }^{5}$. Now we at once recall that earlier in this century, Sinuhe was in this very region, in Qedme, east of Kepn (Byblos), where he found Enshi son of 'Amu, chief of the upper Tenu, and lived in the land of Yaa, while his sons (?) ruled in Qedm, Khentkesh, and the lands of the Fenkhu (Phoenicians?) ${ }^{6}$.

The great Shamshi-Adad was followed by Ishme-Dagan, by .... ashshat, and by Rimush. Then comes another group headed by Adasi, to whom and to whose son Belibni, Esarhaddon points with pride as ancestors. He calls Adasi the "founder of the kingdom of Assyria," which should mean that he freed Ashur from the control of the kingdom on the Euphrates. The remainder of this group have peculiar names, Shabai, Sharma-Adad I, Gizil-Sin, Zimzai, Lullai; one edition of the list of rulers omits the whole group, as if doubtful of their legitimacy.

1 So Koldewey, Babylon, 165 ; cf. Die Hettitische Inschrift.

${ }^{2} K B o$. I, 10 of Hattushilish III; Luckenbilt, AJSL. XXXVII, 200.

$3 C f$. Olmstead, $A J S L$. XXXVI, 121, n. 6.

* Olmstead, JaOS. XXXVIII, $241 \mathrm{n}$.

5 Fully discussed, Olmstead, AJSL. XXXVI, 127.

${ }^{\circ}$ Gandinkr, Notes on Sinulhe (sep. ed.), $168 \mathrm{fl}$. 
These kings fill the first half of the eighteenth century ${ }^{1}$. They are names and nothing more, and they are characteristic of our knowledge of the period throughout the whole of the Near East. In Babylonia, the so-called second dynasty was of no account, in the north anarchy was closed by the sack of Babylon by Gandash in 1745 and the establishment of the third or Kashshite dynasty. In Egypt, the glorious Twelfth Dynasty had closed a generation earlier, 1788, and only local princelings contended with each other in never ending struggles.

During this period of utter darkness in the older countries, there appear the Hyksos, and they give us reason to believe that when excavations are carried on elsewhere, we shall find civilization in the Hyksos home. But where should we look for the centre of this Hyksos power? There can be no doubt that it was north east of Egypt, for Hatshepsut calls them Amu or Asiatics ${ }^{2}$, Manetho could identify them with the Hebrews ${ }^{3}$, Avaris was made their centre to be near their Syrian lands, and it was in Syria they resisted when driven out of Egypt.

Their greatest king was Khian ${ }^{4}$. His name is the same as the Haianu of Samal who fought with Shalmaneser III ${ }^{5}$. His title, "Lord of the Seacoast (?)," in a Chicago Art Institute cylinder seal ${ }^{6}$, should refer to the Mediterranean coast of Syria, and recalls the claim of Shamshi-Adad I to the shore of the great sea. On some of his seals, he has the twisted rope design, characteristic of the "Hittite" seals found in north Syria ${ }^{\text {. }}$

All this points to connection with the north Syrian region claimed by Shamshi Adad. Another connection with another part ruled by Shamshi-Adad is the Baghdad lion. The fact that it was there before $1861^{8}$ seems to preclude its being carried in modern times from Egypt. Those who deny its Egyptian origin look to Babylon as its source. This is virtually excluded on chronological grounds. If Khian had ruled Babylon after 1745, we should be virtually certain of references, while Egyptian chronology places Khian something like a century later than this date. In fact, it was somewhere about the time of Khian that Agum-kakrime brought back the Marduk statue from Hana, where was still an independent kingdom. Considering the probabilities of finding, it would be as natural to bring the statue to Baghdad from 'Ana as from Babylon. We may therefore see in the lion an indication that the Hana region was under the control of Khian, but with full recognition of the precariousness of the evidence. The only thing we can say is that the evidence, such as it is, all hangs together and all points to the North Syrian-West Mesopotamian region as the centre of the Hyksos power.

About the same time that the third dynasty began in north Babylonia, a new dynasty commences in Ashur. The names of the new rulers are Pan-Ninua, Sharma-Adad II, Erishum III, Shamshi-Adad II, Ishme-Dagan II, Shamshi-Adad III, an unknown, PuzurAshur III, Enlil-nasir I, Nur-ili, Ishme-Dagan III. Again we have names and nothing more (1756-1551, WEIDNER), but the names at least have significance. They are certainly west Semitic, with their frequent invocation of the two west Semitic gods of that group, Adad and Dagan. Two Shamshi-Adads and two Ishme-Dagans can only be named in imitation of the great Shamshi-Adad and his son. Perhaps the connection with the Euphrates was renewed. Were these kings rulers of Ashur in the first place or only

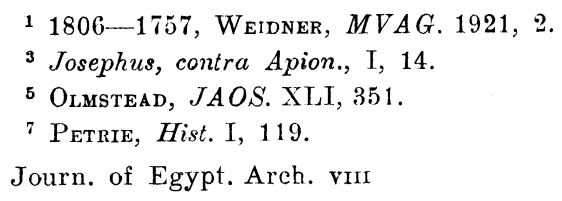

2 Breasted, Rec. II, 125; Paton, Rec. XIX.

4 Material collected, Paton, Rec. XI.

6 Pier, AJSL. XXIII, 78; PAton, Rec. XI.

8 Devéria, Mémoives I, 217. 
incidentally? We have no inscriptions with their titularies to give answer, though one of the later kings recognizes Ashur in his own name. Were they part of a greater kingdom, whether of the Hyksos or of a Mesopotamian kingdom opposed to them? The lion of Khian which came probably from Mesopotamia speaks in favor of the first alternative, but is there a possibility that there is some element of truth in the statement of Manetho that the Hyksos specially fortified the eastern frontier as they feared possibility of invasion from the Assyrians, then the greatest power ${ }^{1}$ ?

Egypt suddenly came alive about 1580, drove out the Hyksos and brought Syria under her control. Already Ahmose (1580-1557) had invaded Zahi, that is Egyptian armies had reached central Syria ${ }^{2}$, and he claims the Fenkhu, in whom we can hardly see other than the Phoenicians. ${ }^{3}$. Amenophis I may have raided all Syria, since his successor Thutmose I claims a boundary at the Euphrates before his own travels thither ${ }^{4}$, and later he was at Niy and hunted elephants in Naharina ${ }^{5}$. During the reign of Hatshepsut (1501-1479), it was possible to bring cedars from as far north as Kepn (Byblos) ${ }^{6}$. Unfortunately, this is our entire amount of information; we have no details and it remains a moot point just how far this country, and especially the interior, was in Egyptian hands.

When Thutmose III began his first campaign, in 1479, the Egyptian hold on Syria was largely lost and the reason is probably to be found in the developing power of the Hittites. Archaeology shows a neolithic civilization in Asia Minor. The socalled Cappadocian tablets are the archives of a "factory" of Semitic traders who were settled in Mazaka in the time of the Ur dynasty of Babylonia, the twenty-fifth century before Christ. There are startling analogies to the Assyrians. The god Ashir is often honoured in their names and in language they suggest relationship to the Assyrian dialect. On one seal is the impress of a well known governor of Ashur, the city from which these merchants must have set forth. It was from these that the nations of Asia Minor learned cuneiform.

About the time that Hatshepsut began to rule, say about 1500 , we have the first known king of the Hittites, the father of Hattushilish I, who conquered Hubishna: Tuwwanua, the well known Tyana, the home of the anti-Christ Appolonius: Nenashsha, the classical Nanessos ${ }^{7}$ : Landa, the classical Leandis ${ }^{8}$ : Zallara: Mashshuhanta: and Lu...na. The third of these kings, Murshilish, took Halpash, that is Aleppo; this brings him into contact with the Egyptians, but the question of the date brings up a difficult problem .

When Thutmose III began his first expedition, 1679, all Syria seems to have been lost. Even Sharuhen, on the extreme southern boundary, was in revolt though the decisive battle with the king of Kadesh was fought in Megiddo. The next year, 1678, we have Thutmose listing the "tribute" of a "chief of Ashur," lapis lazuli, vessels of colored stone, horses, wagons, and valuable woods. The Egyptian pompously calls it tribute, but there is no reason to assume that it was delivered as such; the analogy of later and similar relations makes it probable that we have here too actual alliance between Assyria and Egypt. Assyria desired aid against Babylonia and protection against Mitanni; for Egypt, Assyria was an enemy in the rear of Mitanni and perhaps might

\footnotetext{
1 Josephus, contra Apion., I, $14 . \quad 2$ Breas'ted, Rec. II, 10; Paton, Rec. XV.

3 Breasted, Rec. II, 13; Paton, Rec. XIV. + So Breasted, Hist. 254; Rec. II, 31 ; Paton, Rec. XVT.

5 Breasted, Rec. II, 125 (but of Thutmose I); Setue, Urkunden IV, 103 ; Paton, Rec. XV.

6 Sethe, Urkunden IV, 534 ff.; Paton, Rec. XX. ${ }^{7}$ Rasisat, Hist. Geog. Asia Minor, 285.

s Ibid., 311.

9 KBo. III, 1; Hrozný, Keilschrifttexte, $90 \mathrm{ff}$.
} 
be made of avail against the Hittites. It is most unfortunate that Thutmose does not give us the name of the Assyrian ruler, but we can conjecture; the Assyrian line continues from where we left it with Ashur-nirari, with whom we begin to have inscriptions, showing prosperity in the capital, with Puzur-Ashir IV, who made a formal treaty of alliance with Burnaburiash I of Babylonia, with Enlil-nasir II, and with Ashur-rabi I. The date of the last (1490-1470, WEIDNER) makes it probable that he was the king allied with Egypt.

Thutmose did not consider it wise to attack Naharina until 1469, by which time it might be assumed that Assyria had seriously weakened Mitanni. For this same year there is claimed "tribute" of Babylon and of the Hittites. Unfortunately, Thutmose has again deliberately omitted the names of both kings. We must especially regret his failure in the case of Babylonia, for we have no idea as to who was ruling Babylon in this period. It seems too early for Kara-Indash I. The Hittite ruler was probably Murshilish, who instead of telling of tribute sent to Thutmose, rather tells of the capture of Aleppo. He does worse than that, he claims the capture of Babylon ${ }^{1}$ ! Naturally, a conquest of Babylon, especially with the carrying off of the spoil, is as much out of the question as in the case of the Egyptian claims. All we can say with certainty is that Egypt, the Hittites, Babylonia, and Assyria, were in diplomatic relation. The later balancing of power makes it probable that the truth behind all this is that the Hittites and the Babylonians were united against the Egyptians, the Assyrians, and perhaps the Mitannians. One fact is made abundantly clear, that claims of "tribute" are suspect until the contrary is proved.

It may well be that this was the exact time that Murshilish took Aleppo, that the "tribute" from the Hittites masks the confessed loss of that centre. At any rate, two years later, in 1467, he again marks an expedition against Naharina-Mitanni. Another tribute of the chief (sic) of the great Kheta is mentioned in 1461 and in 1460 he must again fight with Naharina ${ }^{2}$.

The Hittite usurper extended his territory to Hurpanash (Herpa, Arabissos), to Tagarma, the Togormah of the Hebrews and the Til Garimmu of Sargon, about Derende on the Tokhma Su, west of Malatia ${ }^{3}$. Next is placed his capture of Carchemish, which Thutmose had just claimed for himself. The death of Hantilish must belong about 1450, so that by the death of Thutmose III (1447), the Egyptians seem to have lost control of the extreme north of Syria.

Thus in the first year of Amenophis II, it was necessary to conquer again all central and north Syria which was in full revolt. Naharina was once more defeated and Mitanni, "a country which knew not Egypt"," sought "favour." The "tribute" here claimed from Mitanni probably marks an alliance of Mitanni and Egypt, for the Mitannian king of the time, Saushshatar, invaded Assyria and took doors of gold and silver and set them up in his palace of Washshukkani ${ }^{5}$. The Assyrian king is not mentioned. It can hardly be Ashirnirari II, about 1470-1450, more probably it was Ashir-bel-nisheshu or his brother

1 The form of the name, Ka-dinger-ra, makes it absolutely certain that the Babylon is meant.

2 Amenemhab fought near Aleppo and Carchemish, and this is probably to be placed in 1469 , Breasted, Rec. II, 231; Paton, Rec. XXXII.

3 Olmstead, Sargon, 92; he also took the cities of Arzamia (Arzapia?) and Shallapash (?).

4 Breasted, Rec. II, 317 though in contact under Thutmose III, ib. 265, 301.

5 KBo. I, 1 f.; Luckenbil., A.JSL. XXXVII, 172. 
Ashur-rim-nisheshu who made a friendly agreement with the Babylonian Kara-Indash I. The Hittite rulers of this period were Huzziash (1450-1430), the result of another palace revolution, who gave way to Telibunush, the author of the inscription which has told us all that has gone before. His own exploits were in the region of the later Isauria, the cities taken being Hashshuwash, Zizzilibbi, Lawazzandiash, the latter the classical Lauzados ${ }^{1}$.

With Thutmose IV (1420-1411) comes the first of a series of marriages with Mitanni which show that that country is definitely allied with Egypt. This was with the daughter of Artatama, successor of Saushshatar, and the letter in which it is mentioned shows that it came after a series of peaceful negotiations ${ }^{2}$; Thutmose however claims that he won spoil on his first campaign against Naharina ${ }^{3}$. He also "established true brotherhood" with a king of Babylonia, whom we may assume to be Kara-Indash I, whose reign is about $1420-1408^{4}$.

Through the Mitannian marriage, Amenophis III (1411-1375) was the grandson of Artatama of Mitanni, and so half Asiatic himself. It was therefore natural that he should be on good terms with his uncle, Shutarna of Mitanni, and that in true Asiatic fashion he should receive his cousin Giluhipa in marriage (1401) ${ }^{5}$. Shutarna died shortly after this and was succeeded by Tushratta, whose daughter Taduhipa became the wife of Amenophis IV ${ }^{6}$. Amenophis III was also on good terms with Ashur-nadin-ahe (1410-1390) of Assyria and sent him a subvention in gold ', but this did not prevent his cousin Tushratta from filling his palace with the treasure brought as the "tribute" by "the Assyrian"." Nineveh was his, and in his insolence he went so far as to exile Ishtar from her belored city that she might visit with her healing his mighty cousin ${ }^{9}$. Ashur himself was counted as a subordinate Mitannian god ${ }^{10}$.

With Babylonia begging for gold ${ }^{11}$, with Assyria receiving a subvention, and under the control of his cousin of Mitanni, with Syria his in greater part, with the king of Alashia (Cyprus) begging him not to ally himself with the Hittites ${ }^{12}$, the position of Amenophis III might seem destined to a reign of the widest power and prosperity.

An example illustrates the untruth of this. Nuhashshe has been assumed to be Egyptian because of the way it appears in the Amarna letters; Tushratta realized that it was really independent under its king Sharrupsha, and made an attempt to secure it for Mitanni. Its king appealed to the Hittites where Hattushilish II had been succeeded by his son Shuppiluliuma ${ }^{13}$. The Hittite army soon secured all Mitannian territory west of the Euphrates, took Teburzia ${ }^{14}$ on the opposite bank, devastated Ishua ${ }^{15}$, gave a captive city to Antaratli of Alshe ${ }^{16}$, then, recrossing the river, he took Halba (Aleppo) where Akit-Teshub had raised a conspiracy against his brother Takuwa, the enemy nominee for king of Nia (Niy). Then he turned against Nuhashshe and Sharrupsha escaped with his life, leaving his servant Takib-sharri to be appointed in his place. On the way to

\footnotetext{
1 RaMSAY, Hist. Geog. 370 .

4 Knudizon, 1.

7 KnUdTzon, 16.

$10 K B o . \mathrm{I}, 1 \mathrm{f}$.

13 KBo. I, 4; LUckenbill, AJSL. XXXVII, 177.

14 The Assyrian Til Barsip, ff. Olmstead, JAOS. XLI, 353.

15 Olmstead, JAOS. XLI, $360 \mathrm{n}$.

16 The Assyrian Alzi, Olmstead, JAOS. XXXVII, 170; XLI, 360.

? Schroeder, $12 ;$ Kinudtzon, 29.

5 Breasted, Rer. 1I, 347.

s KBo. I, 1.

11 KNud'Tzon, $1 \mathrm{ff}$.
}

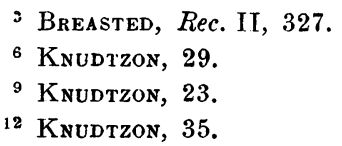

12 Knudtzon, 35. 
Abina ${ }^{1}$, Shuppiluliuma professed no intention of attacking Kinza, but when Shutarna marched out against him with his chariots, he could only reply in kind, and Shutarna joined Ariwana of Abina in exile in the Hittite capital ${ }^{2}$.

Tushratta claimed the return of the Hittite king as a victory and sent a gift to his Egyptian relative from the spoil ${ }^{3}$. Evidently the natives of Mitanni were less optimistic about the victory, for they shortly after deposed him.

Before this happened, Amenophis III passed away and left a troubled throne to his son Amenophis IV. Ikhnaton (1375-1358) as he is more generally called, was not interested in foreign affairs. When Shuppiluliuma wrote him his congratulations on his accession ${ }^{4}$, Akhenaton remembered his intrigues in north Syria and his battles with the friendly Mitanni. He seems to have refused reply. The Amarna letters are full of the details of the advance of Shuppiluliuma into Syria, but the details are out of place here. Finally, Aziru of Amurru was brought to make one of the usual one-sided treaties with the Hittite monarch and north Syria was lost to Egypt ${ }^{5}$. Whether Egypt and the Hittites actually came to blows is uncertain, but quite possible ${ }^{6}$.

His failure to stand up against the Hittites permitted Tushratta's son Artatama II to displace his father. He remained content with the title "King of Harri," and handed over Mitanni to his son Shutarna to the prejudice of another son of Tushratta, Mattiuaza, who fled to the Hittite king. In his perilous situation, Artatama must make peace with some of his enemies. He chose the Assyrians and Alshe and to the disgust of the Hittite king rewarded each, and sent home the famous gold and silver doors robbed from Assyria. Akit-Teshub fled to Babylonia, but its king was allied to the Hittites and his possessions were confiscated and he himself threatened with death. With the aid of Shuppiluliuma, Mattiuaza won back a part of his heritage, and another son-in-law of the Hittite, Biashshilim recovered Carchemish ${ }^{7}$.

"The Assyrian" often appears in these narratives and at the close he is declared to have sued for peace. His name is deliberately concealed, but we learn from other sources that he was Ashur-uballit, the son of Eriba-Adad, the first of the men who created the Assyrian empire. At his accession, he ruled but a few square miles about Ashur and his very independence was doubtful; at its close, Assyria had won recognition as one of the great powers and Babylon recognized his protection. The troubles in Mitanni were of the greatest advantage to Assyria. Ashur might be no longer invoked among the gods of Mitanni and Ishtar of Nineveh once more became an Assyrian; her recovery was celebrated by the restoration of her temple. The wide extending Shubari represented a part of the spoils extorted from Mitanni ${ }^{8}$.

The letter by which he made reply to the coming of ambassadors from Amenophis IV has been preserved. He addresses the Egyptian as brother, in full insistence upon equality, and he suggests gold as subsidy, since his grandfather Ashur-nadin-ahe had received so much ${ }^{9}$. Burnaburiash II of Babylon protested vigorously to the Egyptian court against

1 Olmstead, JAOS. XLI, 367.

$2 K B o . \mathrm{I}, 1 \mathrm{f}$.

3 Kivupzos, 17.

4 KNUDTzon, 41.

5 KBo. I, 8; Luickenbilt, AJ.SL. XXXVIT, 197.

"Meissner, ZDMG. LXXIJ, 34, finds evidence for this in the statement in the Ramesses treaty that Saplel had already made a treaty with an Egyptian king; it may only relate to such connections as are shown by the letter quoted above.
7 KBo. I, $1 \mathrm{f}$.
8 Detailed account, Ormstrad, AJSL. XXXVI, 130.
9 Knudtzon, 16. 
the recognition accorded the Assyrians, his rassals ${ }^{1}$, but his predecessors had made too many treaties with their former subjects, and if Assyria had more recently lost complete autonomy, it was to Mitanni and not to Babylonia.

Arik-den-ilu (1325-1310), the next Assyrian, conquered Halah and Qummuh ${ }^{2}$, that is, the greater part of Mitanni became his, and Adad-nirari (1310-1280) made still greater advances. The long reign of Shuppiluliuma had been followed by those of his sons Arnuwandash and Murshilish. Halab (Aleppo) was bound anew with its king Rimsharma ${ }^{3}$. Kissuwadna or Cilicia, was recovered from the Harri, to the advantage of its king Shuna-Ashshura, whose name bore the same acknowledgement of the might of Ashur that we find in those of the business men who wrote the Cappadocian tablets a thousand years earlier ${ }^{4}$.

The last act of Murshilish was a war with Seti I of Egypt (1313-1295) $)^{5}$. The conflict was not confined to these combatants, for we find Nazi-Maruttash (1321-1295) of Babylonia warring with the Assyrians, and presumably he was a Hittite ally. This time the Assyrians won ${ }^{6}$.

Peace was soon after made between Seti and the new Hittite monarch, Muwatallish ${ }^{7}$, but the truce was not of long duration, for under Ramesses II (1292-1225) the war broke out with renewed violence. The new king of the Hittites wrote to the new king of Babylonia, Kadashman-Turgu (1295-1278), that he had been forced to wage a defensive war against the Egyptians, and received a favorable reply; that Babylonia sent actual aid is uncertain nor is it likely that there was again war between Assyria and Babylonia ${ }^{8}$. The battle of Kadesh was celebrated by Ramesses in poem and temple relief ${ }^{9}$, but the Hittite records ${ }^{10}$ told a different story. In his heart, Ramesses realized that he was fighting a losing battle and appealed to the growing Assyrian power. Adad-nirari responded, at least to the extent of sending gifts, and a promise of aid; the Egyptian took a mean advantage and in his annals called these presents by the ugly name of tribute $(1282)^{11}$.

1 Knudtzon, 9.

2 Halah, Olmstead, Sargon, 71; AJSL. XXXVI, 133. Qummuh, JAOS. XXXVII, 170.

3 KBo. I, 6; Meissner, ZDMG. IXXXII, $35 \mathrm{f}$; Luckenbill, $A J S L$. XXXVII, 188.

4 KBo. I, 5; Meissner, ZDMG. LXXII, 36 f.; Luckenbill, AJSL. XXXVII, $180 \mathrm{ff}$. The detailed boundary permits us to draw the boundary between the Hittites and Kissuwadna with almost exact precision. It begins with the sea, not the Black Sea as Luckenbiul, but the Mediterranean. The first place mentioned is Lamia, the classic Lamos, in the Lamotis district, and on the Lamos river, the modern Ijamas Su, Ramsay, Hist. Geog. Asia Minor, 380. It is thus the extreme west of Cilicia Trachaea. Bituratu is not known. Next is Aruna, which, if the famous city elsewhere mentioned, is at last located with exactness. Its later successor must have been the equally well known Olba, RAMsAY, 374, with ruins at Ura, though perhaps the older place may be at Oren Köi, see map by F. Schafrkr, Jahreshefte Austr., 1902, $106 \mathrm{ff}$. The latter name, "Ruin Village," cannot however be counted as proof of identification with Aruna. Shalia is Soli, which has given us our English word solecism. After Anamushta comes Zabarina, which is Zephyrium, RAMsAy, 384. Turutuna is about where we should expect Tarsus. Atania is of course the more than well known Adana. Luwana may recall the Aleian Plain. Durbina and Sherigga are not known, but the Shamri river is the boundary and the Shamri can only be the Sarus or Seihun river, which certainly deserves the name of a "raging" river. The last place mentioned is Zilabbuna.

5 Breasted, Rec. III, 72.

- Cf. Olmstead, AJSL. XXXVI, 134.

7 Some make it a treaty between Murshilish and Horemheb, see IaAngdon-Gardiner, Journal VI, $190,203$.

${ }^{8} K B o . \mathrm{I}, 10$; Luckenbill, $A J S L$. XXXVII, $200 \mathrm{ff}$.

${ }^{10} K B o$. I, 15, 19; Meissner, ZDMG. LXXİI, $37 \mathrm{ff}$.

9 Breasted, Battle of Kadesh.

11 Breasted, Rec. III, 162. 
How much this distraction aided Egypt, we cannot say; to Assyria the war was a godsend, for Mesopotamia no longer feared Hittite armies. The writer of a badly broken letter found in the Hittite archives tells his correspondent that in the days of Adad-nirari Hani-Galbat had been invaded and destroyed ${ }^{1}$. The king himself chronicles the capture of Shubari, of Carchemish, of Harran, the most important city in Mitanni, and of Kashiari, the rough country south of the west Tigris, which represented the most easterly point to which the Hittite arms had penetrated?

Shalmaneser I (1280-1260) determined to follow his father's example in lopping off some more territory from the Hittite possessions in Mesopotamia. Unfortunately for him, this was just the moment when there came a sudden change in affairs. The antiEgyptian Muwatallish was put out of the way by his brother Hattushilish III. It would seem that Urhi-Teshub, the son of Muwatallish fled to Ramesses, and that his surrender was the price of peace ${ }^{3}$. Later, Hattushilish could bemoan the fact that when he ascended the throne, Ramesses had sent him no congratulations ${ }^{4}$ ! But the peace was made ${ }^{5}$.

This peace was most unfortunate for Shalmaneser. When the king of Mitanni began to suspect the next Assyrian objective, he sent to his Hittite overlord a letter, telling: how Hani-Galbat had been destroyed by Adad-nirari. He complains that a king of Shupria has been invited by his lord as protection against the writer, seizing his throne, so that now the king of Shupria is destroying the land by oppression ${ }^{6}$.

So when Shalmaneser had penetrated the difficult defiles into the Mitanni land he found him supported by his Hittite master. This was more than Shalmaneser had bargained for, and when the Hittites seized the passes, the invaders began to suffer from want of water. Shalmaneser claims the final victory, but the fact that he must use the exact words of his father when claiming victories from Taidi to Carchemish makes us somewhat suspicious. By the conquest of Qummuh, a wedge was driven far into the former territory of the Hittites; to make its control more sure, Shalmaneser planted at Halsi-Luha, in the triangle of fertile land north of Amedi, a colony which endured for four centuries?

Further advance was prevented by the troubles which Hattushilish had stirred up on the southern boundary. The Hittite had been allied with Kadashman-Turgu; he attempted to renew the alliance when Kadashman-Enlil succeeded, but failed at first because his guardian, Itti-Marduk-balatu, had not liked the tone of his letter.

Intercourse was renewed when Kadashman-Enlil came of age, but the newly found brotherhood was soon endangered when news began to filter in of an agreement between Hittites and Egyptians. The Hittite reply was somewhat ambiguous. The former enemies have become brothers, will fight with a common enemy and with a common friend will be at peace. But after all there are contingencies through which the new alliance might be broken. For instance, if the extradition clause does not work, the kings will be angry with one another; if Ramesses aids his enemy, there will be war. If Egypt has prevented

1 KBo. I, 20; Leckenrilt, AJSL. XXXVIT, $209 \mathrm{f}$. $2 C f$. Olmstend, AJSL. XXXVT, $133 \mathrm{HI}$.

$3 C f$. the discussion by Meissner, ZDMG. I.XXII, $43 \mathrm{ff}$.

$4 K B o . \mathrm{I}, 14$; Meissven, ZDMG. LXXII, 44 f.; I,cckenbill, $A J S L$. XXXVII, $205 \mathrm{ff}$.

5 Egyptian text, Breasted, Rec. III, $163 \mathrm{ff}$; the Hittite copy, KBo. I, 7, 25; discussion of relations between the two, Meissner, $S B$. Berl. 1917, $282 \mathrm{ff}$; ZDMG. LXXII, 46 ff.; Langdon-Gardiner, Journal VI, $179 \mathrm{fr}$; Luckenitr., AJSL. XXXVIT, $190 \mathrm{ff}$.

6 KBo. I, 20; Luckexbill, AJSL. XXXVII, 209 f. $\quad 7$ ' $f$. Olmstead, A.JSL. XXXVI, $135 \mathrm{ff}$. 
the transmission of official letters from Babylonia to the Hittite land, Kadashman-Enlil should take action. Hattushilish is properly shocked by such a confession of weakness as that his messengers have been discontinued because of attacks by the Ahlame along the Euphrates. It is a word which is not good, and thereby the sovereignty of his brother suffers detraction.

The most serious sinner is Assyria. If its king detains a Babylonian ambassador in his land, this is an act of war, and surely Babylonia is not a conquered land. What king of Assyria is powerful enough to restrain his messengers? Kadashman-Enlil is a mighty man of valour, a youthful wild bull. The writer at last comes out plainly and begs him to go and spoil the hostile land, and kill his enemy, for the king who lays aside his weapons is sure to suffer in the end. Though the enemy land be three or four times as great as his own, let him march against it ${ }^{1}$.

Such an attack against Assyria did actually take place. We are not told the result but we can conjecture. After a brief reign (1278-1270), the greater part of it in his minority, Kadashman-Enlil disappeared. Hattushilish had worked upon his youthful vanity to his destruction ${ }^{2}$.

The last of the great Assyrian kings of the period was Tukulti-Ninib (1260-1232). Our records become more and more scanty. Assyria suffered from a series of weak kings and suffered from usurpations. For a period, it was even subject to Babylon. The alluvium had a moment of prosperity under Nebuchadnezzar I (1146-1120 [?]), but his successors were of little account. Egypt was slowly going down hill under the Twentieth Dynasty, whose kings were less and less able to hold their own at home. A son, Dudhalia, and a grandson, Arnuwandash II, followed the Hittite Hattushilish, and as late as the time of the second Aleppo and Carchemish were still in the Hittite sphere of influence, though fighting was necessary to retain their control ${ }^{3}$.

Our knowledge of Asia Minor and of north Syria comes to an end and the history is a literal blank for centuries. As the older civilized powers disappeared, barbarism descended. By the beginning of the fourteenth century, isolated Hebrew tribes, the Habiri of the Amarna letters, were working their way into Palestine, and with the breakdown of Egyptian rule there ensued those struggles so vividly portrayed in the book of Judges. Foiled in the attack on Egypt, the Philistines settled along the coast of the land to which they were to give the name of Palestine. In north Syria, the kingdom of Amurru, which we last see under Bantishinni as a Hittite vassal state ${ }^{4}$, seems to have lasted long enough to give later writers a picture of a great Amorite empire ${ }^{5}$. Soon it went down before the attacks of invading Aramaean tribes, who likewise settled in Mesopotamia and even in Babylonia. It may be that the Hittite empire fell beneath the blows of the Minoans who were being driven out by the invading Indo-Europeans ${ }^{6}$. But all is conjecture, since for their "period of the Judges" we have no contemporary tales.

$1 K B o . \mathrm{I}, 10$; Luckenbill, AJSL. XXXVIT, $200 \mathrm{ff}$. wrongly assigned to Kadashman-Turgu; Meissner, $Z D . M G$. LXXII, 45.

$2 C f$. Olmstead, AJSL. XXXVI, 139.

3 KBo. I, 11; Luckenbill, AJSL. XXXVII, 207. 4 KBo. I, 8; Luckenbill, AJSL. XXXVII, 197 ff.

$5 C f$. the evidence collected by Chax, Empire of the Amorites.

${ }^{6}$ MeYse, Chetiter, 70; W. Otto, Hist. Zeit. CXVII, 225; MeIssver, ZD.MG. LXXII, 64. 